\title{
Pengaruh Komunikasi, Kompensasi dan Disiplin Kerja terhadap Kinerja Karyawan pada PT. The Univenus di Sidoarjo
}

\author{
*Rahayu Dinda, Nurul Qomari, Enny Istanti \\ Program Studi Manajemen Fakultas Ekonomi dan Bisnis \\ Universitas Bhayangkara Surabaya, Indonesia
}

DOI: $10.46821 /$ benchmark.v2i1.223

\begin{abstract}
Abstrak
Penelitian ini bertujuan untuk mengetahui pengaruh komunikasi, kompensasi dan disiplin kerja terhadap kinerja karyawan. Analisis ini menggunakan variabel independen: komunikasi, kompensasi dan disiplin kerja, variabel dependen: kinerja karyawan. Metode penelitian ini menggunakan penelitian kuantitatif, pengukuran variabel menggunakan jenis data skala likert dengan menyebar kuesioner. Populasi dalam penelitian ini adalah karyawan PT. The Univenus di Sidoarjo dengan jumlah karyawan sebanyak 120 orang. Teknik pengambilan sampel ini dilakukan dengan menggunakan probability sampling yang dilakukan dengan mengambil sampel dari sampel yang terpilih. Kriteria sampel dalam penelitian ini adalah karyawan PT. The Univenus di Sidoarjo dengan jumlah sampel sebanyak 92 orang. Teknik analisis yang digunakan adalah teknik analisis regresi linier berganda dengan menggunakan Uji F, Uji t serta Uji Dominan dengan taraf signifikan 5\% melalui Statistical Package for the Social Science (SPSS). Hasil pengujian terbukti bahwa variabel Komunikasi, Kompensasi dan Disiplin Kerja secara simultan berpengaruh signifikan dengan hasil regresi linier berganda dalam uji $\mathrm{F}$ diperoleh Fhitung sebesar 237,654 lebih besar dari Ftabel sebesar 2,71 sedangkan pengaruh secara parsial yang signifikan melalui uji $\mathrm{t}$ diperoleh thitung untuk masing-masing variabel bebas yaitu thitung Komunikasi (X1) sebesar 9,327, Kompensasi (X2) sebesar 2,103 dan Disiplin Kerja (X3) sebesar 6,509 lebih besar dari nilai tabel sebesar 1,662 maka variabel bebas Komunikasi, Kompensasi dan Disiplin Kerja berpengaruh terhadap variabel terikat Kinerja Karyawan sedangkan variabel Komunikasi berpengaruh dominan terhadap Kinerja Karyawan.
\end{abstract}

Kata Kunci: Komunikasi, Kompensasi, Disiplin Kerja dan Kinerja Karyawan.

\section{PENDAHULUAN}

Pada era globalisasi ini persaingan di dunia sudah semakin ketat. Negara Indonesia sedang menghadapi globalisasi ekonomi sehingga Indonesia mampu meningkatkan pembangunan di segala bidang. Sumber daya manusia merupakan modal dasar pembangunan nasional, oleh karena itu, makakualitas sumber daya manusia senantiasa sangat berperan besar dalam kesuksesan organisasi.Setiap organisasi dituntut untuk memiliki Sumber Daya Manusia yang berkualitas dan memilikidaya saing yang tinggi sehingga mampu menjadi energi bagi organisasi untuk bersaing dengankompetitornya di tengah arus perubahan yang semakin dinamis.(Enny Istanti, 2020, 378).

Oleh karena itu untuk memenangkan persaingan, sumber daya manusia (sdm) dituntut untuk bisa menerima perkembangan dan perubahan-perubahan yang terjadi pada lingkungan sekitar mereka, sumber daya manusia ( $\mathrm{sdm}$ ) harus bisa meningkatkan kemampuan dan kualitas dirinya dan selalu berinovasi dengan menciptakan ide-ide yang kreatif bagi perusahaan. Sehingga apa yang diinginkan oleh konsumen bisa terpenuhi 

global.Sinambela,(2018:9) manajemen sumber daya manusia adalah pengelolaan sumber daya manusia sebagai sumber daya atau aset yang utama, melalui penerapan fungsi manajemen maupun fungsi operasional sehingga tujuan organisasi yang telah ditetapkan dapat tercapai denganbaik.Pengelolahan SDM dilakukan sebagai suatu strategi untuk meningkatkan kinerja karyawan sehingga dapat meningkatkan produktivitas perusahaan kinerja sering digunakan sebagai indikasi prestasi atau tingkat keberhasilan individuatau kelompok. Kinerja dapat dilihat dari suatu kegiatan dalam mewujudkan sasaran, tujuan, visi dan misi organisasi.

Hamali, (2018:224) komunikasi adalah seseorang mencoba membagi informasi, gagasan atau sikap dengan yang lain agar diperoleh presepsi yang sama.komunikasi merupakan proses penyampaian informasi dari dua arah antara komunikator kepada komunikan yang dapat memberikan informasi dan ide-ide sesuai dengan tujuannya.Kasmir, (2019:335) kompensasi adalah merupakan hak karyawan atas jasanya membantu perusahaan mencapai tujuannya. Dan sebaliknya merupakan kewajiban perusahaan untuk membayar atas kontribusi yang telah diberikan, baik berupa tenaga, pikiran maupun waktu selama bekerja.

Sinambela, (2018:335) disiplin kerja adalah suatu alat yang digunakan pemimpin untuk berkomunikasi dengan pegawai agar mereka bersedia untuk merubah pola perilaku mereka mengikuti arahan atau aturan yang sudah diterapkan.Berdasarkan uraian latar belakang diatas, maka peneliti tertarik mengadakan penelitian yang berjudul "Pengaruh Komunikasi, Kompensasi dan Disiplin Kerja Terhadap Kinerja Karyawanpada PT. The Univenus Sidoarjo".

\section{TINJAUAN PUSTAKA}

\section{Komunikasi}

Hamali (2018:224) menyatakan bahwa komunikasi adalah suatu proses penyampaian ideide dan informasi berupa perintah dan petunjuk kerja dari seseorang pimpinan kepada karyawan atau para bawahannya untuk melaksanakan tugasnya dengan sebaik mungkin. Purwanto dalam Ginting, (2018:28) dalam melakukan komunikasi yang efektif ada beberapa indikator yang perlu dilakukan, diantaranya:

a. Persepsi

Komunikasi harus dapat memprediksi apakah pesan-pesan yang akan disampaikan dapat diterima oleh penerima pesan. Audiens sebagai penerima pesan lalu akan mengantisipasi reaksi komunikator untuk menyusun pesan penyesuaian untuk menghindari kesalahfahaman dalam komunikasi tersebut.

b. Ketepatan

Secara umum audiens mempunyai suatu kerangka berfikir. Agar komunikasi yang dilakukan mencapai sasaran, maka seseorang perlu mengekspresikan sesuatu sesuai denga napa yang ada dalam kerangka berfikir mereka,apabila hal itu diabaikan, maka yang muncul adalah miss communication.

c. Kredibilitas

Dalam berkomunikasi komunikator perlu memiliki suatu keyakinan bahwa para audiens adalah orang-orang yang dapat dipercaya. Demikian jugasebaliknya, komunikator harus mempunyai suatu keyakinan akan inti pesan dan maksud yang ingin mereka sampaikan. 
d. Pengendalian

Dalam berkomunikasi, audiens akan memberikan suatu reaksi atau tanggapan terhadap pesan yang disampaikan. Reaksi mereka dapat membuat komunikator tertawa, menangis, bertindak, mengubah pikiran, atau lemah lembut. Hal ini ditentukan oleh intensitas reaksi yang dilontarkan audiens terhadap apa yang disampaikan oleh komunikator. Sebaliknya reaksi audiens tergantung pada berhasil atau tidaknya komunikator mengendalikan audiensnya saat melakukan komunikasi.

e. Keharmonisan

Komunikator yang baik tentu akan selalu dapat menjaga hubungan yang baik dengan audiens sehingga komunikasi dapat berjalan lancar dan mencapai tujuannya.

\section{Kompensasi}

Hasibuan (2019:59), kompensasi adalah semua pendapatan yang berbentuk uang, barang atau tidak langsung yang diterima karyawan sebagai imbalan dan jasa yang diberikan kepadaperusahaan.Simamora dalam Zulkarnaen dan Sudarma, (2018:341) indikator untuk mengukur kompensasi karyawan ada tiga, yaitu:

a. Gaji

Gaji adalah suatu bentuk imbalan kerja berupa uang yang diterima karyawan untuk setiap periode tanpa memperhatikan jumlah jam kerja.

b. Tunjangan

Tunjangan adalah suatu penghargaan tidak langsung yang diberikan oleh perusahaan kepada karyawan sebagai bagian dari keanggotaan organisasi tanpa menghiraukan kinerja.

c. Fasilitas

Fasilitas adalah sarana dan prasarana yang diberikan oleh perusahaan untuk memudahkan pekerjaan karyawan seperti peralatan kantor, transportasi dan alat komunikasi.

\section{Disiplin Kerja}

Hasibuan (2019:193) menyatakan bahwa disiplin adalah kesadaran dan kesediaan seseorang menaati semua peraturan di dalam perusahaan dan norma-norma sosial yang berlaku.Hasibuan dalam Eulin Karlina, (2019:131) indikator-indikator disiplin kerja yaitu antara lain:

a. Absensi tenaga kerja

Absen adalah tidak hadirnya karyawan ke tempat kerja yang disebabkan bermacammacam alasan. Adapaun sebab dari adanya absen adalah alpa,iijin, dan sakit.

b. Adanya keterlambatan

Adanya keterlambatan kerja diluar kebiasaan sebagai faktor dari turunnya kedisiplinan kerja karyawan yang pada umumnya disebabkan karena kurangnya rasa tanggung jawab atas pekerjaanya. Misalnya kemalasan atau meninggalkan tempat kerja.

c. Perputaran tenaga kerja (LTO)

Labour Turn Over (LTO) adalah keluar masuknya tenaga kerja atau perputaran karyawan disuatu organisasi dengan ukuran tertentu. 
d. Seringnya terjadi kesalahan

Seringnya terjadi kesalahan dalam melakukan pekerjaan ini mungkin disebabkan oleh faktor diluar manusia seperti kesalahan sistem material, kerusakan mesindan lain sebagainya.

e. Adanya pemogokan

Dengan adanya pemogokan berarti menunjukan bahwasannya tenaga kerja itu tidak mempunyai rasa kedisiplinan. Pemogokan merupakan perwujudan dari ketidakpuasan, kegelisahan dan lainnya.

\section{Kinerja Karyawan}

Hendy Tannady (2017:154), kinerja adalah hasil kerja secara kualitas dan kuantitas yang dicapai seorang karyawan kepada suatu perusahaan dalam melaksanakan tugas dan targetnya sesuai dengan tanggung jawab yang diberikan kepadanya. Robbins dalam Sopiah dan Sangadji, (2018:351) ada enam indikator untuk mengukur kinerja karyawan, yaitu:

a. Kualitas, kualitas kerja diukur dari persepsi pimpinan terhadap kualitas pekerjaan yang dihasilkan serta kesempurnaan tugas terhadap keterampilan dan kemampuan karyawan.

b. Kuantitas merupakan jumlah yang dihasilkan, biasanya dinyatakan dalam istilah seperti jumlah unit, jumlah siklus aktivitas yang diselesaikan.

c. Ketepatan waktu merupakan tingkat aktivitas diselesaikannya pekerjaan dalam waktu tertentu yang sudah ditetapkan sebagai standar pencapaian waaktu penyelesaian pekerjaan.

d. Efektivitas merupakan tingkat penggunaan sumber daya organisasi (tenaga, uang, teknologi, bahan baku) dimaksimalkan dengan maksud menaikkan hasil dari setiap unit dalam penggunaan sumberdaya.

e. Kemandirian merupakan tingkat seorang karyawan yang nantinya akan dapat menjalankan fungsi kerjanya, komitmen kerja. Merupakan suautu tingkat dimana karyawan mempunyai komitmen kerja dengan instansi dan tanggung jawab karyawan terhadaporganisasi.

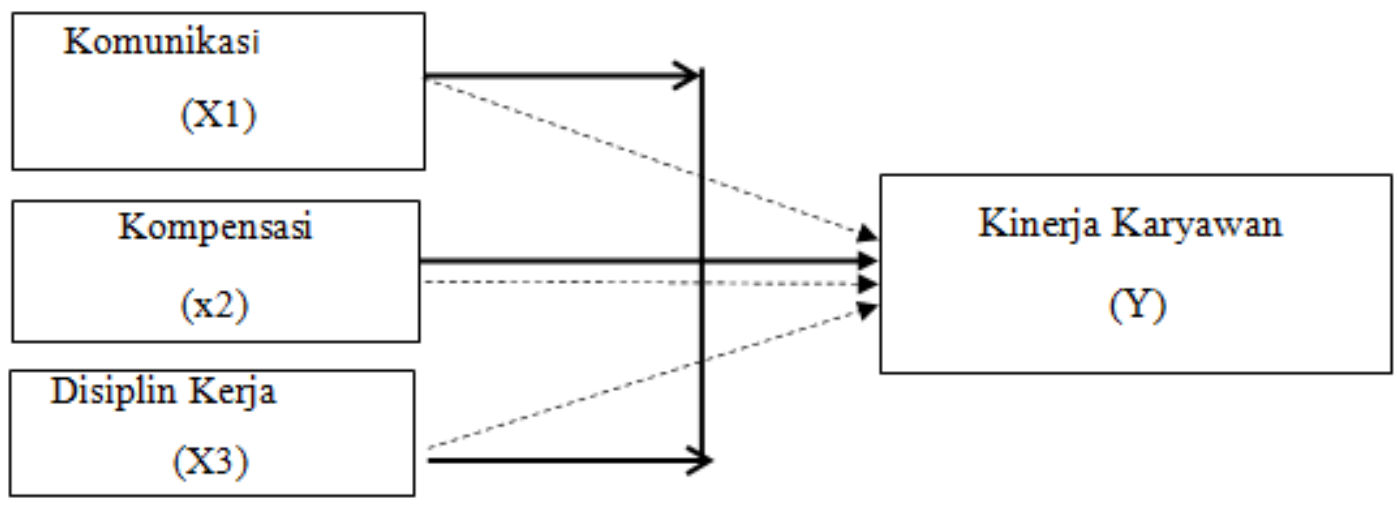

\section{Gambar 1}

Kerangka Konseptual 


\section{Hipotesis}

a. Bahwa variabel Komunikasi, Kompensasi dan Disiplin Kerja secara simultan berpengaruh signifikan terhadap Kinerja Karyawan pada PT. The Univenus Sidoarjo.

b. Bahwa variabel Komunikasi, Kompensasi dan Disiplin Kerja secara parsial berpengaruh signifikan terhadap Kinerja Karyawan pada PT. The Univenus Sidoarjo.

c. Bahwa variabel Disiplin Kerja secara dominan berpengaruh terhadap PT. The Univenus Sidoarjo.

\section{METODE PENELITIAN}

\section{Populasi}

Sugiyono (2019:126) menyatakan bahwa populasi adalah wilayah generalisasi yang terdiri atas obyek atau subyek yang mempunyai kuantitas dan karakteristik tertentu yang ditetapkan oleh peneliti untuk dipelajari dan kemudian ditarik kesimpulannya. Jadi populasi bukan hanya orang, tetapi juga objek dan benda-benda alam yang lainnya. Populasi juga bukan sekedar jumlah yang ada pada objek atau subjek yang dipelajari, tetapi juga meliputi seluruh karakteristik atau sifat yang dimiliki oleh subjek itu. Populasi dalam penelitian ini adalah karyawan pada PT. The Univenus Sidoarjo 120orang.

\section{Sampel}

Sugiyono (2019:127), sampel adalah bagian dari jumlah dan karakteristik yang dimiliki oleh populasi tersebut. Tekni pengambilan sampel pada penelitian ini menggunakan teknik probability sampling, yang dimana menurut Sugiyono (2019:129) yaitu teknik pengambilan sampel yang memberikan peluang yang sama bagi setiap unsur (anggota) populasi untuk dipilih sebagai anggota sampel. Dalam penelitian ini menggunakan 92 sampel.

\section{Lokasi dan Waktu Penelitian}

Lokasi dari objek penelitian adalah PT. The Univenus Sidorajo yang beralamat di Jl.Raya Surabaya Krian Km 26, Ds Keboharan, Kecamatan Krian, Sidoarjo, JawaTimur. Waktu penelitian dilakukan pada bulan Desember 2020-November 2021 dilakukan sampai dengan data yang diperlukan sudah lengkap sesuai dengan kebutuhan peneliti.

\section{Teknik Pengumpulan Data}

Pengumpulan data yang diperlukan dalam penelitian ini melalui tahap berikut, yaitu:

a. Wawancara (interview)

Wawancara adalah sebuah proses memperoleh keterangan untuk tujuan penelitian dengan cara tanya jawab sambil bertatap muka antara pewawancara dengan responden atau yang diwawancarai, dengan atau tanpa menggunakanpedoman wawancara. Wawancara digunakan sebagai teknik pengumpulan data apabila ingin melakukan studi pendahuluan untuk menemukan permasalahan yang harus diteliti.

b. Kuisioner (Angket)

Kuisioner merupakan teknik pengumpulan data yang dilakukan dengan cara memberi seperangkat pertanyaan atau pernyataan tertulis kepada responden untuk dijawabnya. Kuisioner merupakan teknik pengumpulan data yang efisien apabila 
peneliti tahu dengan pasti variabel yang akan diukur dan tahu apa yang bisa diharapkan dari responden (Sugiyono, 2019:199).

c. Observasi

Observasi merupakan suatu proses yang kompleks, suatu proses yang tersusun dari berbagai proses biologis dan psikologis, dua diantara yang terpenting adalah prosesproses pengamatan dan ingatan (Sugiyono, 2019:203).

d. Dokumen

Dokumen yaitu pengumpulan data dengan cara mencari dan menyalin data- data atau dokumen perusahaan yang berhubungan dengan obyek yang diteliti.

\section{HASIL ANALISIS DAN PEMBAHASAN}

Analisis Linier Berganda

Berdasarkan tabel 1, maka persamaan regresi yang terbentuk pada uji regresi ini adalah: $\mathrm{Y}=0,047+0,512 \mathrm{X} 1+0,171 \mathrm{X} 2+0,378 \mathrm{X} 3+\mathrm{e}$

\section{Uji Koefisien Determinasi $\mathbf{R}^{2}$}

Hasil analisis regresi berganda yang terdapat pada Tabel 2 didapatkan nilai koefisien korelasi berganda $(\mathrm{R})$ sebesar 0,943 , hal ini menunjukkan bahwa antara variabel bebas dan variabel terikat mempunyai tingkat hubungan dengan kategori sangat kuat. Adapun hasil koefisien determinasi $\left(\mathrm{R}^{2}\right)$ didapatkan sebesar 0,890 atau 89\%. Artinya bahwa variabel bebas mampunyai pengaruh terhadap variabel terikat sebesar $89 \%$, sedangkan sisanya sebesar $11 \%$, dipengaruhi oleh faktor lain yang tidak termasuk dalam variabel penelitian ini.

\section{Uji F (Uji Simultan)}

Hasil pengujian model secara bersama-sama (simultan) pada Tabel 3 diperoleh nilai $F_{\text {hitung }} 237,654$ sebesar nilai ini lebih besar dari pada $F_{\text {tabel }}$ sebesar 2,71Demikian juga nilai signifikan yaitu $\alpha=5 \%$ atau 0,05 . Sehingga dapat disimpulkan bahwa $\mathrm{H}_{0}$ ditolak dan $\mathrm{H}_{1}$ diterima. Artinya variabel Komunikasi, Kompensasi, dan Disiplin Kerja secara bersamasama (simultan) memiliki pengaruh yang signifikan terhadap Kinerja Karyawan (Y) pada PT. The Univenus Sidoarjo.

Tabel 1

Analisis Regresi Linier Berganda

Coefficients $^{\mathrm{a}}$

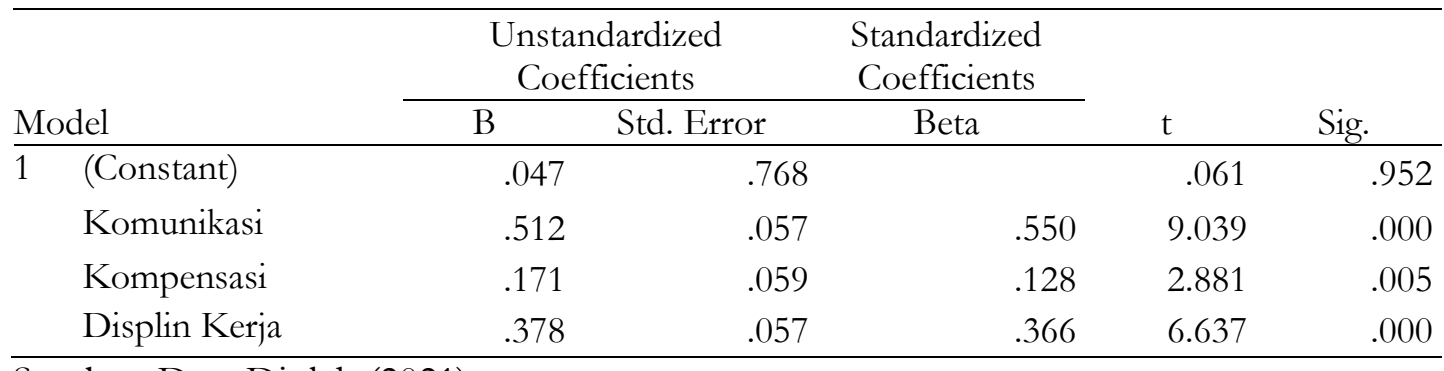

Sumber: Data Diolah (2021) 
Tabel 2

Koefisien Korelasi dan Determinasi Model Summary

\begin{tabular}{|c|c|c|c|c|c|c|c|c|c|}
\hline \multirow[b]{2}{*}{ Model } & \multirow[b]{2}{*}{$\mathrm{R}$} & \multirow[b]{2}{*}{$\begin{array}{c}\mathrm{R} \\
\text { Square }\end{array}$} & \multirow{2}{*}{$\begin{array}{c}\text { Adjuste } \\
\text { d R } \\
\text { Square } \\
\end{array}$} & \multirow{2}{*}{$\begin{array}{l}\text { Std. Error } \\
\text { of the } \\
\text { Estimate }\end{array}$} & \multicolumn{5}{|c|}{ Change Statistics } \\
\hline & & & & & $\begin{array}{c}\text { R Square } \\
\text { Change }\end{array}$ & F Change & df1 & df2 & $\begin{array}{l}\text { Sig. F } \\
\text { Change }\end{array}$ \\
\hline 1 & $.943 a$ & .890 & .886 & .834 & .890 & 1 & $.943 a$ & .890 & .886 \\
\hline
\end{tabular}

Tabel 3

Hasil Uji F (Simultan)

ANOVA $^{\mathrm{a}}$

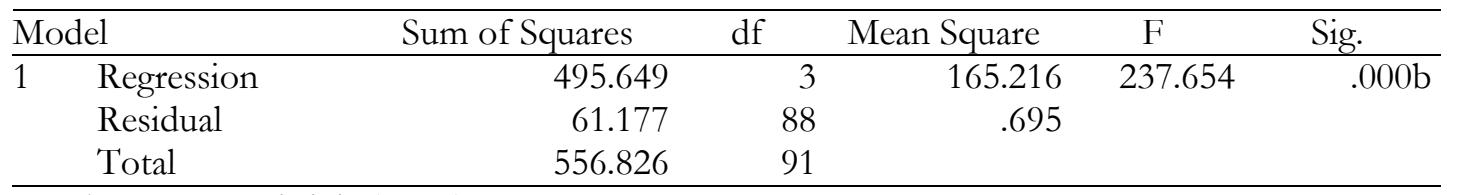

Sumber: Data Diolah (2021)

\section{Tabel 4}

Hasil Uji t (Parsial)

\begin{tabular}{|c|c|c|c|c|c|c|}
\hline \multirow{2}{*}{\multicolumn{2}{|c|}{ Model }} & \multicolumn{2}{|c|}{$\begin{array}{c}\text { Unstandardized } \\
\text { Coefficients }\end{array}$} & \multirow{2}{*}{$\begin{array}{c}\text { Standardized } \\
\text { Coefficients }\end{array}$} & \multirow[b]{2}{*}{$\mathrm{t}$} & \multirow[b]{2}{*}{ Sig. } \\
\hline & & $\mathrm{B}$ & Std. Error & & & \\
\hline \multirow[t]{4}{*}{$\overline{1}$} & (Constant) & .047 & .768 & & 1 & .952 \\
\hline & KOMUNIKASI & .512 & .057 & .550 & 9.327 & .000 \\
\hline & KOMPENSASI & .171 & .059 & .128 & 2.103 & .005 \\
\hline & DISPLIN KERJA & .378 & .057 & .366 & 6.509 & .000 \\
\hline
\end{tabular}

Sumber: Data Diolah (2021)

\section{Uji t (Parsial)}

Tabel 4 menunjukkan hasil uji hipotesis yaitu (1) Komunikasi memiliki nilai signifikan $0,000>0,05 \mathrm{H}_{0}$ ditolak dan $\mathrm{H}_{1}$ diterima. Hal ini menunjukkan bahwa secara parsial variabel komunikasi $\left(\mathrm{X}_{1}\right)$ berpengaruh signifikan terhadap Kinerja Karyawan (Y).(2) Kompensasimemiliki nilai signifikan 0,005 $<0,05$ maka $\mathrm{H}_{0}$ ditolak dan $\mathrm{H}_{1}$ diterima. Hal ini menunjukkan bahwa secara parsial variabel Kompensasi $\left(\mathrm{X}_{2}\right)$ berpengaruh signifikan terhadap Kinerja Karyawan (Y). (3) Disiplin Kerja memiliki nilai signifikan signifikan $0,000<0,05$ maka $\mathrm{H}_{0}$ ditolak dan $\mathrm{H}_{1}$ diterima. Hal ini menunjukkan bahwa secara parsial variabel Disiplin Kerja $\left(\mathrm{X}_{3}\right)$ berpengaruh signifikan terhadap Kinerja Karyawan (Y).

\section{Pembuktian Variabel Dominan}

Dari tiga variabel yang terdiri dari Komunikasi $\left(\mathrm{X}_{1}\right)$, Kompensasi $\left(\mathrm{X}_{2}\right)$, Disiplin Kerja $\left(\mathrm{X}_{3}\right)$, dapat diketahui bahwa variabel Komunikasi $\left(\mathrm{X}_{1}\right)$ mempunyai nilai koefisien $\beta$ (beta) terbesar yaitu 0,550 yang merupakan nilai terbesar diantara variabel-variabel bebas yang lain, sehingga dapat disimpulkan bahwa variabel bebas berpengaruh dominan terhadap variabel Kinerja Karyawan (Y) adalah Komunikasi $\left(\mathrm{X}_{1}\right)$ (Tabel 5). 


\begin{tabular}{|c|c|c|c|c|c|}
\hline \multicolumn{6}{|c|}{$\begin{array}{c}\text { Tabel } 5 \\
\text { Hasil Pembuktian Dominan }\end{array}$} \\
\hline \multirow[b]{2}{*}{ Model } & \multicolumn{2}{|c|}{$\begin{array}{c}\text { Unstandardized } \\
\text { Coefficients }\end{array}$} & \multirow{2}{*}{$\begin{array}{c}\begin{array}{c}\text { Standardized } \\
\text { Coefficients }\end{array} \\
\text { Beta } \\
\end{array}$} & \multirow[b]{2}{*}{$\mathrm{t}$} & \multirow[b]{2}{*}{ Sig } \\
\hline & B & Std. Error & & & \\
\hline $\begin{array}{ll}1 \text { (Constant) } \\
\end{array}$ & .047 & .768 & & .061 & .952 \\
\hline KOMUNIKASI & .512 & .057 & .550 & 9.039 & .000 \\
\hline KOMPENSASI & .171 & .059 & .128 & 2.881 & .005 \\
\hline DISPLIN KERJA & .378 & .057 & .366 & 6.637 & .000 \\
\hline
\end{tabular}

Sumber: Data Diolah (2021)

\section{Pembahasan}

\section{Uji Hipotesis Pertama Secara Simultan (Uji F)}

Berdasarkan hasil penelitian dapat dikatakan bahwa variabel Komunikasi, Kompensasi dan Disiplin Kerja secara simultan berpengaruh terhadap variabel Kinerja Karyawan. Artinya dapat disimpulkan bahwa $\mathrm{H}_{0}$ ditolak dan $\mathrm{H}_{1}$ diterima. Artinya variabel Komunikasi, Kompensasi dan Disiplin Kerja secara bersama-sama (simultan) berpengaruh signifikan terhadap Kinerja Karyawan (Y) pada PT. The Univenus Sidoarjo.

Dalam penelitian ini koefisien korelasi berganda (R) sebesar 0,943, hal ini menunjukkan bahwa antara variabel bebas dan terikat mempunyai tingkat hubungan dengan kategori sangat kuat. Adapun hasil koefisien determinasin $\left(\mathrm{R}^{2}\right)$ didapatkan sebesar 0,890 atau $89 \%$. Artinya bahwa variabel bebas mempunyai pengaruh terhadap variabel terikat sebesar $89 \%$, sedangkan sisanya sebesar 11\% dipengaruhi oleh faktor lain yang tidak termasuk dalam variabel penelitian ini. Komunikasi, Kompensasi dan Disiplin Kerja berpengaruh signifikan terhadap Kinerja Karyawan. Apabila Komunikasi yang dilakukan karyawan dengan tepat, adanya tanggung jawab karyawan sesuai dengan aturan yang ditetapkan untuk meningkatkan kompensasi, serta disiplin kerja yang semakin nyaman dan memenuhi standart, maka diharapkan kinerja karyawan pada PT. The Univenus Sidoarjo akan meningkat. Dengan demikian hipotesis penelitian yang menyatakan bahwa Kompensasi, Disiplin Kerja, dan Lingkungan Kerja secara simultan berpengaruh signifikan terhadap kinerja karyawan PT. The Univenus Sidoarjo ternyata terbukti kebenarannya.

\section{Uji Hipotesis Kedua Secara Parsial (Uji t)}

\section{Pengaruh Komunikasi $\left(\mathbf{X}_{1}\right)$ Terhadap Kinerja Karyawan (Y)}

Dalam penelitian ini, pengujian secara parsial dengan uji t untuk mengetahui pengaruh Komunikasi terhadap Kinerja Karyawan diperoleh bahwa nilai $t_{\text {hitung }} \geq t_{\text {tabel }}$ dan nilai signifikan yang dihasilkan sebesar 0,000 yang jauh lebih kecil dari 0,05 maka $\mathrm{H}_{0}$ ditolak dan $\mathrm{H}_{1}$ diterima. Artinya variabel Komunikasi secara parsial berpengaruh signifikan terhadap Kinerja Karyawan pada PT. The Univenus Sidoarjo.Dengan demikian hipotesis penelitian yang menyatakan bahwa Komunikasi secara parsial berpengaruh signifikan terhadap kinerja karyawan PT. The Univenus Sidoarjo ternyata terbukti kebenarannya. 
Dalam penelitian ini, pengujian secara parsial dengan uji $\mathrm{t}$ untuk mengetahui pengaruh Kompensasi terhadap Kinerja Karyawan diperoleh bahwa nilai $t_{\text {hitung }} \geq t_{\text {tabel }}$ dan nilai signifikansi yang dihasilkan sebesar 0,005 yang jauh lebih kecil dari 0,05 , maka $\mathrm{H}_{0}$ ditolak dan $\mathrm{H}_{1}$ diterima. Artinya variabel Kompensasi secara parsial berpengaruh signifikan terhadap Kinerja Karyawan pada PT. The Univenus di Sidoarjo.Dengan demikian hipotesis penelitian yang menyatakan bahwa Kompensasisecara parsial berpengaruh signifikan terhadap kinerja karyawan PT. The Univenus Sidoarjo ternyata terbukti kebenarannya.

\section{Pengaruh Disiplin Kerja $\left(\mathbf{X}_{3}\right)$ Terhadap Kinerja Karyawan (Y)}

Dalam penelitian ini, pengujian secara parsial dengan uji $\mathrm{t}$ untuk mengetahui pengaruh Disiplin Kerja terhadap Kinerja Karyawan diperoleh bahwa nilai $t_{\text {hitung }} \geq t_{\text {tabel }}$ dan nilai signifikansi yang dihasilkan sebesar 0,000 yang jauh lebih kecil dari 0,05 , maka $\mathrm{H}_{0}$ ditolak dan $\mathrm{H}_{1}$ diterima. Artinya variabel Disiplin Kerja secara parsial berpengaruh signifikan terhadap Kinerja Karyawan pada PT. The Univenus di Sidoarjo. Dengan demikian hipotesis penelitian yang menyatakan bahwa Disiplin Kerja secara parsial berpengaruh signifikan terhadap kinerja karyawan PT. The Univenus Sidoarjo ternyata terbukti kebenarannya.

\section{Pengaruh Dominan}

Berdasarkan hasil perhitungan regresi linier berganda diketahui yang memiliki nilai koefisien standart beta ( $\beta$ ) paling besar adalah dari variabel Komunikasi (X1) sebesar 0,550 dibandingkan variabel Kompensasi (X2) 0,128 dan Disiplin Kerja (X3) 0,366. Dari tiga variabel yang terdiri dari Komunikasi $\left(\mathrm{X}_{1}\right)$, Kompensasi $\left(\mathrm{X}_{2}\right)$ dan Disiplin Kerja $\left(\mathrm{X}_{3}\right)$, dapat diketahui bahwa variabel Komunikasi $\left(\mathrm{X}_{1}\right)$ mempunyai nilai koefisien $\beta$ (beta) yaitu 0,550 yang merupakan nilai terbesar diantara variabel-variabel bebas lain. Sehingga dapat disimpulkan bahwa variabel bebas yang mempunyai pengaruh dominan terhadap variabel terikat Kinerja Karyawan adalah variabel Komunikasi $\left(\mathrm{X}_{1}\right)$. Dengan demikian hipotesis yang menyatakan bahwa Komunikasi berpengaruh dominan terhadap kinerja karyawan PT. The Univenus Sidoarjo ternyata tidak terbukti kebenarannya karena nilai beta variabel Komunikasi sebesar 0,550.

\section{SIMPULAN DAN SARAN}

Berdasarkan hasil penelitian dan pembahasan yang digunakan sesuai dengan hipotesis yang dilakukan dengan menggunakan analisis regresi berganda, maka dapat ditarik simpulan sebagai berikut: (1) Berdasarkan hasil analisis uji $\mathrm{F}$ diperoleh nilai $\mathrm{F}_{\text {hitung }} 237.654$ $>\mathrm{F}_{\text {tabel }} 2,71$ dan dengan taraf Signifikansi $0,000<0,05$. Hal ini dapat disimpulkan bahwa variabel Komunikaksi $\left(\mathrm{X}_{1}\right)$, Kompensasi $\left(\mathrm{X}_{2}\right)$ dan Disiplin Kerja $\left(\mathrm{X}_{3}\right)$ secara simultan atau bersama-sama berpengaruh terhadap Kinerja Karyawan (Y) pada PT. The Univenus Sidoarjo. Menurut peneliti Komunikasi, Kompensasi dan Disiplin Kerja merupakan suatu hal penting yang harus ada disetiap perusahaan agar kita dapat dengan mudah menilai suatu Kinerja Karyawan jika melakukan prosesnya dengan baik maka akan berpengaruh juga terhadap Kinerja Karyawan. (2)Hasil analisis variabel Komunikasi $\left(\mathrm{X}_{1}\right)$, Kompensasi $\left(\mathrm{X}_{2}\right)$ dan Disiplin Kerja $\left(\mathrm{X}_{3}\right)$ secara parsial berpengaruh terhadap Kinerja Karyawan (Y). (a) Berdasarkan uji parsial untuk variabel bebas yaitu variabel Komunikasi 
$\left(\mathrm{X}_{1}\right)$ nilai $\mathrm{t}_{\text {hitung }}$ sebesar 9,327 $>\mathrm{t}_{\text {tabel }}$ sebesar 1,662 dengan nilai signifikan 0,000 lebih kecil dari nilai signifikan yang digunakan yaitu $\alpha=5 \%$ atau 0,05 . Sehingga dapat disimpulkan bahwa $\mathrm{H}_{0}$ ditolak dan $\mathrm{H}_{1}$ diterima. Artinya bahwa variabel Komunikasi secara parsial berpengaruh signifikan terhadap Kinerja Karyawan pada PT. The Univenus Sidoarjo. (b) Berdasarkan uji parsial untuk variabel bebas yaitu variabel Kompensasi $\left(\mathrm{X}_{2}\right)$ nilai $\mathrm{t}_{\text {hitung }}$ sebesar 2.103 nilai ini lebih besar dari pada $t_{\text {tabel }}$ sebesar 1,662dengan nilai signifikan 0,005 lebih kecil dari nilai signifikan yang digunakan yaitu $\alpha=5 \%$ atau 0,05 Sehingga dapat disimpulkan bahwa $\mathrm{H}_{0}$ ditolakdan $\mathrm{H}_{1}$ diterima. Artinya bahwa variabel bebas Kompensasi secara parsial berpengaruh signifikan terhadap Kinerja Karyawan pada PT. The Univenus Sidoarjo. (c) Berdasarkan uji parsial untuk variabel bebas yaitu Disiplin Kerja (X3) nilai $t_{\text {hitung }}$ sebesar 6,509. Nilai ini lebih besar daripada $t_{\text {tabel }}$ sebesar 1,662. Demikian juga dengan nilai signifikan yang dihasilkan sebesar 0,000 lebih kecil dari nilai signifikan yang digunakan yaitu $\alpha=5 \%$ atau 0,05 . Sehingga dapat disimpulkan bahwa $\mathrm{H}_{0}$ ditolak dan $\mathrm{H}_{1}$ diterima. Artinya bahwa variabel bebas Disiplin Kerja secara parsial berpengaruh signifikan terhadap Kinerja Karyawan pada PT. The Univenus Sidoarjo. (3) Dari ketiga variabel bebas yang terdiri dari Komunikasi $\left(\mathrm{X}_{1}\right)$, Kompensasi $\left(\mathrm{X}_{2}\right)$ dan Disiplin Kerja $\left(\mathrm{X}_{3}\right)$ dapat diketahui bahwa variabel Komunikasi mempunyai nilai koefisien beta terbesar yaitu sebesar 0,550 diantara variabel-variabel bebas yang lainnya. Sehingga dapat disimpulkan bahwa variabel bebas yang berpengaruh dominan terhadap variabel Kinerja Karyawan adalah variabel Komunikasi.

\section{DAFTAR PUSTAKA}

Enny Istanti. (2020). Pegawai Menggunakan Metode Analysis Gap di Kantor Kecamatan Simokerto Surabaya, Jurnal Ilmiah Edunomika, 04 (02), 378-385.

Enny Istantia, Achmad Daengs GSb, Fadjar Budiantoc, Indah Noviandarid, R. S. (2020). The Influences of Motivation, Work Milieu, and Organizational Commitment on Teacher Performance in MTS Negeri 4 ( Public Islamic School), Surabaya East Java. International Journal of Innovation, Creativity and Change, 13(2), 629-642. www.ijicc.net.

Enny Istanti, Amaliyah, Achmad Daengs, G. (2020). Work Productivity Through Compensation, Experiences, and Walfare Benefits PT Summit Otto Finance Surabaya. SINERGI, 10(2), 27-36.

Enny Istanti1, Bramastyo Kusumo Negoro2, A. D. G. (2021). The Effect of Work Stress and Financial Compensation, Ocb on Employee Performance (Case Study at PT. Mentari Sejati Perkasa Private Company in Surabaya). Media Mahardhika, 19(3), 560-569. https://doi.org/10.29062/mahardika.v19i3.280.

Hamali Arif Yusuf. (2018). Pemahaman Manajemen Sumber Daya Manusia. CAPS (Center For Academic Publishing Services). 
Hamali, Y. (2018). Pemahaman Manajemen Sumber Daya Manusia (Cetakan Ke). PT. Buku Seru.

Hasibuan, M. (2019). Manajemen Sumber Daya Manusia (Edisi Revi). PT. Bumi Aksara.

Istanti, E. (2016). Pengaruh Kecerdasan Emosional terhadap Prestasi Belajar Mahasiswa Fakultas Ekonomi Manajemen Universitas Bhayangkara Surabaya. Ekonomika '45, 3 (02), 119. http://jurnal.univ45sby.ac.id/index.php/ekonomi/article/view/119.

Karlina, E. (2019). Manajemen Sumber Daya Manusia. Graha Ilmu.

Kasmir. (2018). Manajemen Sumber Daya Manusia (Teori dan Praktik). PT. Raja grafindo Persada.

Purwanto, D. (2017). Pengaruh Kompensasi, Pengembangan Karir Dan Komunikasi Terhadap Kinerja Karyawan. Jurnal Ilmiah Manajemen, Vol. VII.

Sangadji, S. dan. (2018). Manajemen Sumber Daya Manusia Strategik. ANDI OFFSET.

Sinambela, Poltak, L. (2018). Manajemen Sumber Daya Manusia (Cetakan Ke). PT. Bumi Aksara.

Sudarma, Z. dan. (2018). Pengaruh Gaya Kepemimpinan Transformasional dan Kompensasi terhadap Kepuasan Kerja Karyawan Restoran Warung Taulan Badung. Vo. 17.

Sugiyono. (2019). Metode Penelitian Kuantitatif, Kualitatif dan R\&D. CV. Alfabeta.

Tannady, H. (2017). Manajemen Sumber Daya Manusia (Edisi Pert). Expert. 